\title{
Essentialities of Ratifying CED in Thailand: Human Rights amid Covid-19 Pandemic
}

\author{
Siwarut Laikram ${ }^{1} \oplus$, Shubham Pathak ${ }^{2 *} \odot$ \\ ${ }^{1}$ School of Political Science and Laws, Walailak University, Thai Buri, Tha Sala and 80160, Thailand. \\ ${ }^{2}$ College of Graduate Studies (CGS), Walailak University, Thai Buri, Tha Sala and 80160, Thailand.
}

\begin{abstract}
The Covid-19 pandemic delayed the ratification of several internal laws, reforms, and amendments, especially in developing countries such as Thailand, resulting in limited human rights for the populations. There is a unique violation of human rights inclusive of the right to life, the right not to be tortured, the right to liberty and safety of persons which are very important to international and civil society. This research explores the enforcement measures of the International Convention for the Protection of All Persons from Enforced Disappearance (CED). Thailand is currently in the process of ratifying its membership in CED. This ratification process will contribute towards Thailand for holding an important position to fulfill its obligations as a State Party member of this Convention. Thailand has been drafting internal laws and regulations to be consistent with the CED to recognize and protect lawful human rights. People must not be forced to disappear because such action is a serious criminal offence that must be punished appropriately under the CED. In addition, the injured persons shall be treated fairly and equally in accordance with the objectives and purpose of CED, and the Member of Parliament (MP) shall legislate and support the enactment in accordance with the Convention's obligations. In accordance with international mechanisms, these measures will further enhance the promotion and protection of Thailand's human rights. Therefore, Thailand should complete the ratification process at the earliest to develop more efficient domestic legal measures and mechanisms. Similarly, ratification would be consistent with Article 16 of the Sustainable Development Goals (SDGs), which will contribute to security and enhance a peaceful society by providing access to justice to all people in Thailand.
\end{abstract}

\section{Keywords:}

Human Rights;

Covid-19 Pandemic;

International law;

Enforced Disappearance;

Sustainable Development Goals.

Article History:

$\begin{array}{llll}\text { Received: } & 24 & \text { October } & 2021 \\ \text { Revised: } & 21 & \text { December } & 2021 \\ \text { Accepted: } & 08 & \text { January } & 2022 \\ \text { Published: } & 07 & \text { February } & 2022\end{array}$

\section{1- Introduction}

In the past, no matter how many years in Thailand, there were often cases related to enforced abductions until this generation. Many cases may be related to government politics in part. Forced disappearance, or enforced disappearance, is a term in international human rights law that refers to a case where a person is subjected to an official government, political organization, or others who have been abducted with the support or recognition of the state or political organization [1]. In other words, the state, political organization, or such other persons refusing to acknowledge their fate or residency of the missing persons deliberately placing them outside the legal protection. Therefore, it is understandable that victims of enforced disappearance are often killed in the event of abduction or unlawful restraint. In addition, the victim may be subjected to torture during the extraction of information. Killing, gagging, and then hiding the body to disguise the case so that evidence of death cannot be found. And the offender can be denied liability, and

* CONTACT: shubhampathak@gmail.com, shubham.pa@wu.ac.th

DOI: http://dx.doi.org/10.28991/esj-2022-SPER-05

(C) 2022 by the authors. Licensee ESJ, Italy. This is an open access article under the terms and conditions of the Creative Commons Attribution (CC-BY) license (https://creativecommons.org/licenses/by/4.0/). 
the victim will eventually disappear. However, Thailand has several political surrender cases, and to this day, it is still unknown what their fates are.

The International Convention for the Protection of All Persons from Enforced Disappearance 2010 (CED) is one of the international human rights treaties that have acted on the crime of directly enforced disappearance. It is one of the international human rights treaties that directly enforces the law on the crime of enforced disappearance [2]. It is a legal instrument influenced by the Convention against torture and the legal execution of inhuman treatment or humiliation. The Rome Statute on the International Criminal Court was adopted by the United Nations General Assembly (UNGA) resolution at its 61st session. The International Convention for the Protection of All Persons from Enforced Disappearance (CED) means the arrest, detention, kidnapping, or any other act depriving a person or group of liberties committed by a government official or implicitly authorized, supported, or accepted by the state, which is often followed by a denial of the deprivation of liberties or concealing the fate or whereabouts of the missing person [3].

This Convention is based on the Declaration on the Protection of All Persons from Enforced Disappearance adopted by the United Nations General Assembly in 1992, but it is not legally binding. Therefore, the UN initiated the idea of drafting a legally binding agreement to recognize the seriousness of enforced disappearance, especially in certain circumstances that constitute a crime against humanity. And to illustrate the collective commitment of the international community to vigorously defend the rights of individuals [4], Thus, this convention was created and is open to all members of the United Nations to sign and become parties. The Convention on the Protection of All Persons from Enforced Disappearance came into force on December 23, 2010 [5]. The obligations under this Convention define enforced disappearance as a criminal offence under the domestic law of a State Party by providing that the State has jurisdiction over the offence of enforced disappearance, whether the victim or the accused is committing an offence as a national of the State, whether or not. In the event that a missing person is a national of the state and the commission of an offence has occurred outside its territory, the state of nationality will also have jurisdiction over the matter. In addition, the International Convention for the Protection of All Persons from Enforced Disappearance also requires that the offence of enforced disappearance must not be a political offence capable of extradition between them. As for issues relating to penalties and statutes of limitations, the International Convention for the Protection of All Persons from Enforced Disappearance is not fixed. But it must be justifiable with the extreme seriousness of the act, and in terms of remedy, the State shall ensure the right of victims and families to be compensated and to receive prompt, sufficient and fair compensation [6].

The enactment of an effective national law by the state is crucial to protect human beings because everyone has a right to life [7]. If we lose freedom or may be subjected to bodily harm, injury, or death, the offender will be punished according to the law. In addition, it is also recognized that the absence of specific laws in Thailand would provide legal loopholes for the Thai government to enforce disappearances with a high probability of enforced disappearances [8]. Interestingly, Thailand would not be blamed for failing to protect the missing person under Thai criminal procedure law due to the need to prove to the judges that the missing person was beaten, shot, killed, or wounded. For instance, if the family did not know the fate of the victim, they could not file the case in the Thai court [9]. Therefore, to make Thailand safe from enforced disappearances, it is necessary to enact the internal law on the Protection of all Persons from Enforced Disappearance as the effective mechanism [10] for guaranteeing the rights and freedoms of the Thai people and reflecting the positive image of Thailand.

This manuscript has been designed to provide a flow towards the analytical approach for this research. The introduction section provided the background of the research gap and essentiality of the CED to be ratified in Thailand [11]. The following sections have been divided into extensive re-evaluated literature reviews to ensure the universal adaptation and cause and effect of ratifying CED. The methodological approach has been mentioned with emphasis on the amalgamated effect of a mixed method approach. The streamlined methodology and combination of qualitative as well as quantitative tools provided for the in-depth analysis and definite results and discussions section. The following section of SWOT analysis depicts the barriers, challenges, and positive hope for the adoption of CED in Thailand. The conclusion provided for reflective outcomes from this research and specific contributions towards existing literature.

\section{2- Literature Review}

The theoretical approach for this legal research has been reform-oriented research in order to analyze the effects of amendments at the policy level implications [12]. The reform oriented legal research provides for intensive evaluation of the adequate existing laws and recommendations towards the better policy level implications. The recommendations evolved through reform oriented research ensure the amendments and adoptions of adequate policies and legal implementations. The analytical and critical research results in enhanced administration policies and provides for adequate legal reforms. Thailand requires a revisit of its national and local level implications. The changing social, economic, and cultural setup among new generations calls for improved legal policies. Adoption of the CED will ensure the security and human rights of the people. 
According to the 2010 International Convention for the Protection of All Persons from Enforced Disappearance, Article 2, the term "enforced disappearance" means the arrest, detention, abduction, or any other form of conduct. Any deprivation of liberty by government officials or a person or group of people who operate with permission, state sponsorship, or tacit recognition. This was followed by a refusal to admit that liberty had been deprived or conceal the fate or whereabouts of a missing person, which resulted in such a person falling outside the protection of the law [13].

The definition of Enforced Disappearance in the 2010 International Convention for the Protection of All Persons from Enforced Disappearance (CED) can be divided into three components:

- There are arrests, detentions, kidnappings or other forms of deprivation of liberty.

- Caused by acts of government officials or other persons but under the power or support or acceptance of the state.

- Refusing to recognize deprivation of liberty or concealment of fate or whereabouts put the missing outside the legal protection.

Consequently, when all three of the above criteria are fulfilled, it shall be deemed enforced disappearance under the International Convention for the Protection of All Persons from Enforced Disappearance immediately, without considering the legislative validity of arrest and detention or not. Also, there is no time limit for how long they will be arrested and imprisoned. If the detention is an act outside the law, it will also place the detainee outside the legal protection of enforced disappearance.

Currently, 63 States Parties have signed and ratified the Convention, and 98 of them have signed the Convention but have not yet ratified it, a process that would bring full force and effect to the Convention, including Thailand and many states that have not yet signed a party to the Convention (Figure 1). Among them are major powers such as Canada, China, the United States, Russia, however, such countries may already have effective domestic laws of protection [14].

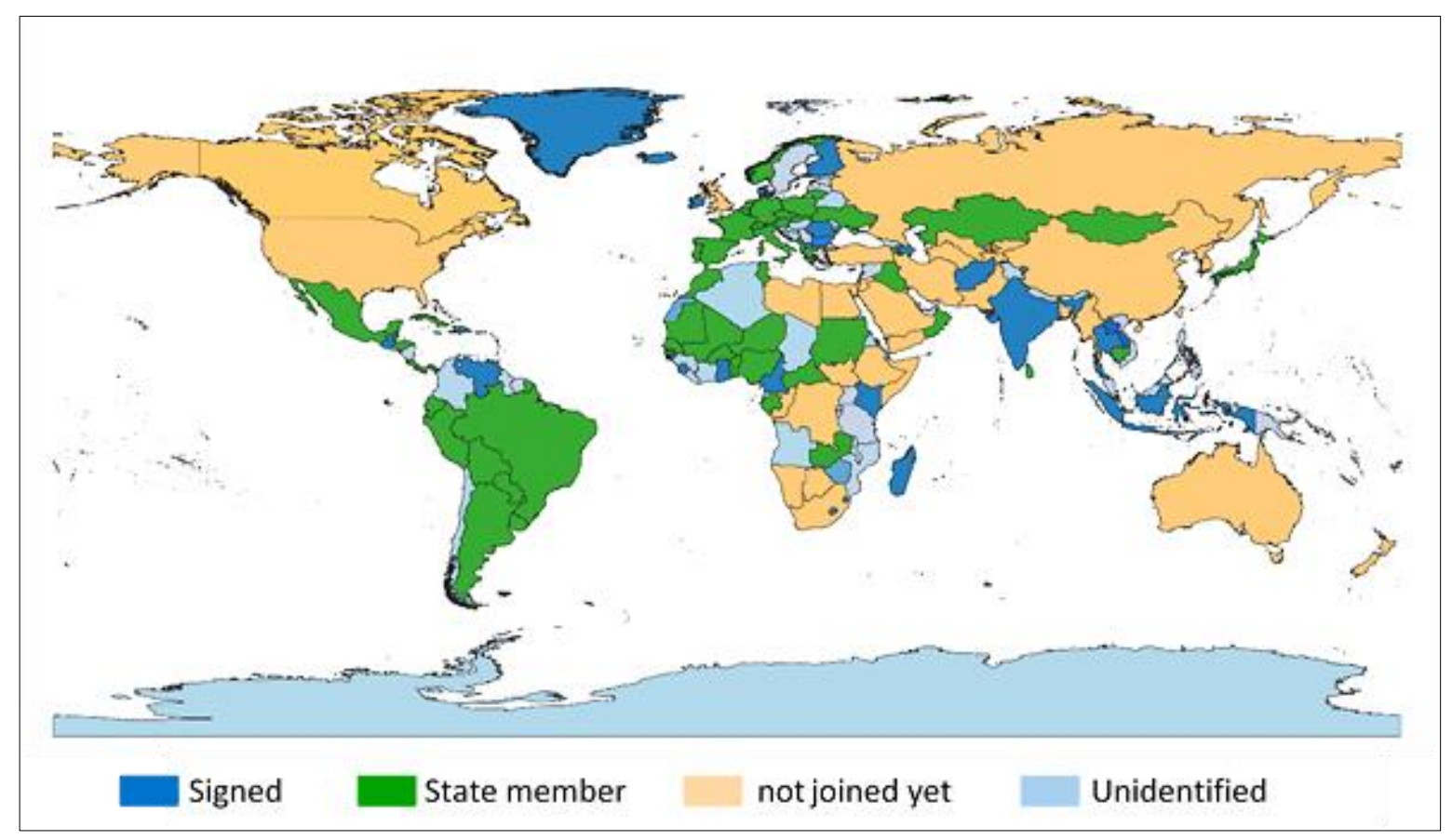

Figure 1. Adapted from United Nation Human Right Office of the High Commissioner

One of the mechanisms of great interest under the International Convention for the Protection of All Persons from Enforced Disappearance is the authorization of the Committee on Enforced Disappearances or the Standing Committee. Convention for the receipt and consideration of claims arising from or acting on behalf of individuals claiming to have been victims of enforced disappearance. This means that individuals can apply directly to the United Nations to consider a resolution or recommendation on the situation. However, the power to accept and consider such requests is not automatic. States parties to the International Convention for the Protection of All Persons from Enforced Disappearance shall first declare recognizing such powers before the Committee on Enforced Disappearance or the Committee on the Convention [15].

The International Convention for the Protection of All Persons from Enforced Disappearance (CED) is a convention signed by Thailand but waiting for ratification for nine years. It is also one of nine major international human rights instrumental treaties under the United Nations that consists of the International Covenant on Civil and Political Rights, the International Covenant on Economic, Social, and Cultural Rights, the Convention on All Forms of Discrimination 
Against Women, the Convention on the Rights of the Child, the Convention on the Elimination of All Forms of Racial Discrimination, the Convention on the Rights of Persons with Disabilities, the International Convention for the Protection of All Persons from Enforced Disappearance, and the Convention on the Protection of the Rights of Migrant Workers and Family Members. Thailand itself has been party to a total of seven international instruments. This does not include the International Convention for the Protection of All Persons from Enforced Disappearance and the Convention on the Protection of the Rights of Migrant Workers and Family Members (See Table 1) [16].

Table 1. The Core International Human Rights Instruments and their monitoring bodies related to Thailand

\begin{tabular}{|c|c|c|c|c|}
\hline No. & $\begin{array}{l}\text { The Core International Human } \\
\text { Rights Instruments and their } \\
\text { monitoring bodies related to Thailand }\end{array}$ & Summary & Date of accession & Effectiveness \\
\hline 1 & $\begin{array}{l}\text { International Covenant on Civil and } \\
\text { Political Rights-ICCPR }\end{array}$ & $\begin{array}{l}\text { Providing the duties of persons to enhance and } \\
\text { protect human rights. Also regulating equal civil, } \\
\text { political, economic, social and cultural rights. }\end{array}$ & October 29,1996 & January 29,1997 \\
\hline 2 & $\begin{array}{l}\text { International Covenant on Economic, } \\
\text { Social and Cultural Rights - ICESCR }\end{array}$ & $\begin{array}{l}\text { The right to regulate a balanced work-life, a } \\
\text { smart well-being education, also enriching good } \\
\text { health and support various culture and non- } \\
\text { discrimination. }\end{array}$ & September 5, 1999 & December 5,1999 \\
\hline 3 & $\begin{array}{l}\text { Convention on the Elimination of All } \\
\text { Forms of Discrimination Against } \\
\text { Women-CEDAW }\end{array}$ & $\begin{array}{l}\text { Equality between men and women in politics, } \\
\text { life, law. Also promoting women's rights to the } \\
\text { economic area, prevention of violence against } \\
\text { women in the workplace and access easily to } \\
\text { health care services, etc. }\end{array}$ & August 9, 1985 & September 8,1985 \\
\hline 4 & $\begin{array}{l}\text { Convention on the Rights of the Child- } \\
\text { CRC }\end{array}$ & $\begin{array}{l}\text { Social welfare for children, civil rights } \\
\text { protection, protection of children in behaviour } \\
\text { problems or committing crimes. }\end{array}$ & February 12, 1992 & April 26, 1992 \\
\hline 5 & $\begin{array}{l}\text { International Convention on the } \\
\text { Elimination of All Forms of Racial } \\
\text { Discrimination - CERD }\end{array}$ & $\begin{array}{l}\text { Human rights and fundamental freedoms of all } \\
\text { human beings without differentiation in race, } \\
\text { sex, language or religion. }\end{array}$ & January 28, 2003 & January 28, 2003 \\
\hline 6 & $\begin{array}{l}\text { Convention against Torture and Other } \\
\text { Cruel, Inhuman or Degrading Treatment } \\
\text { or Punishment - CAT }\end{array}$ & $\begin{array}{l}\text { Defines torture as an offence punishment under } \\
\text { criminal law. Universal jurisdiction on the } \\
\text { offence of torture And the principle of } \\
\text { extradition. }\end{array}$ & October 2, 2007 & November 1,2007 \\
\hline 7 & $\begin{array}{l}\text { Convention on the Rights of Persons with } \\
\text { Disabilities - CRPD }\end{array}$ & $\begin{array}{l}\text { Equality and non-discrimination, women with } \\
\text { disabilities, children with disabilities and raising } \\
\text { awareness about people with disabilities in } \\
\text { society. }\end{array}$ & July 29, 2008 & August 28, 2008 \\
\hline 8 & $\begin{array}{l}\text { International Convention for the } \\
\text { Protection of all Persons from Enforced } \\
\text { disappearance - CED }\end{array}$ & $\begin{array}{l}\text { The enforced disappearance of a person is a } \\
\text { criminal offence, including the penalty. }\end{array}$ & \multicolumn{2}{|c|}{$\begin{array}{c}\text { Signed on Jnuary 9, } 2012 \text { and is in the } \\
\text { process of ratification }\end{array}$} \\
\hline 9 & $\begin{array}{l}\text { Convention on the Protection of the } \\
\text { Rights of Migrants Workers and Member } \\
\text { of their Families - CMW }\end{array}$ & $\begin{array}{l}\text { Protection of workers' rights and family members } \\
\text { in the appropriate international way. }\end{array}$ & \multicolumn{2}{|c|}{ Non-accessioned and non-ratified } \\
\hline
\end{tabular}

Sources: Adapted from United Nation Human Right Office of the High Commissioner [14].

As for the International Convention for the Protection of All Persons from Enforced Disappearance It is a convention that aims to protect individuals from enforced disappearance, which is a crime in a country and, in some circumstances, a crime against humanity. Its main principles are as follows:

- A person shall not be subject to enforced disappearance under any circumstances, such as the state of war, the threat of war, political instability in the country or any other state of public emergency, Article 1 of the International Convention for the Protection of All Persons from Enforced Disappearance [2].

- States shall take appropriate measures to investigate acts of enforced disappearance, such as by arrest, detention, kidnapping or any form of deprivation of liberty by government officials in Articles 2 and Article 3, which shall also be taken as necessary and constitute an offence under domestic criminal law pursuant to Article 4 of the International Convention on the Protection of All Persons from Enforced Disappearance [2].

- Each State Party shall take the necessary measures to expose persons who commit such crimes pursuant to Article 6 of the International Convention for the Protection of All Persons from Enforced Disappearance [2].

- The Convention also establishes a range of methods for dealing with alleged perpetrators, including the issue of extradition between States Parties, the establishment of a Commission on Disappearance by force and many more issues. 
At present, Thailand is not a party to the said convention. Although Thailand had signed the treaty on January 9, 2012, now it is 2021, it has not yet ratified it (Ratification) to become a party to the said Convention. As a result, this convention is not binding on Thailand and Thailand is not obliged to comply with the International Convention on the Protection of All Persons from Enforced Disappearance. However, Article 18 of the Vienna Convention on the Law of Treaties, 1969 [17], although Thailand has not yet been a party, once Thailand has signed it. Thailand is also obligated not to take any action that would violate the intent and purpose of the treaty because the Vienna Convention on the Law of Treaties is subject to customary international law, even if Thailand is not a party. In addition, neighboring ASEAN countries like Cambodia has accessed this Convention since 27 June 2013, which means that if an enforced disappearance occurs in Cambodia, the obligation would comply with this Convention.

\section{2-1-Differences between Ratification and Accession}

The ratification can be defined as a country that initially negotiated a treaty has given its consent to be bound by that treaty. The ratification is like confirmation that the treaty will be legally enforceable in one's country. The ratification is like confirmation that the treaty will be legally enforceable in one's country. This is different from the word accession, which is the case where the bound treaty is already. This must be determined by the type of treaty that states that there is a procedure for signing and the intention to be binding however, may include: (1) In cases where the signing process and the declaration of intent are separate.

The signing is a political intent that is not legally binding under international law to Thailand and includes a process of ratification, notification, approval or acceptance for a treaty to be binding. Any subject to the approval of the Council of Ministers and approve the signature or (2) In cases where the signing process and the declaration of intent come in one step or in the case of being a party to a treaty that has come into force, it must seek approval from the Council of Ministers before signing the treaty, contract or before accession [18].

It can be noted that at present, although Thailand has signed the surrendering convention since 2012, at present it has not yet ratified it to become a party to that convention. Therefore, the question may arise whether signing is not equal to being a party and being bound by an international agreement or not. There is a difference between signing and becoming a party because becoming a party, means becoming a member under a treaty but must meet the terms of the treaty such as conventions, protocols, charters. When becoming a party, that country will have the rights and obligations contained in that treaty and be enforceable between countries that have agreed to be a party to the same treaty. Unless specifically reserved by that country that will not be bound by any of the provisions of the treaty, there shall be no prohibition or prohibition from making such a reservation.

For Thailand, becoming a party to any treaty must be carried out in accordance with the Constitution of the Kingdom of Thailand B.E. 2560 B.E. Most often it is about contracts that affect territorial changes, sovereign rights that affect economic security, society or international trade and investment. The matter must be brought to the Cabinet meeting for approval and/or approval.

Moreover, in accordance with Article 178 paragraph 4 of the Constitution of the Kingdom of Thailand B.E. 2560 (2017) determines the issue of participation in expressing opinions and obtaining necessary remedies arising from the impact of the contract [19]. Therefore, these steps, including enacting national legislation at the statutory level known as the Prevention and Suppression of Torture and Enforced Disappearance Act, in which must be drafted to cover the entire scope of enforcement of Criminal offences and many more issues [20]. However, after Thailand signed on January 9, 2012, until now, after nine years have passed, why is it insufficient for Thailand to complete its accession as a party to the convention?

\section{2-2-Law and Practical Steps of Being a Party}

Article 8 of the International Convention for the Protection of All Persons from Enforced Disappearance provides an opportunity for all Member States of the United Nations to sign. But this signing does not constitute consent to be legally binding. The expression of consent to be bound is merely an expression of an intention to become a party in the future. The signatory states have delivered the Instrument of Ratification, confirmed to the Secretary-General of the United Nations once again. The deposition of this instrument of ratification constitutes consent to be bound by the Convention. However, the state's status as a party to the Convention has required ratification, then it shall apply to the State granting that legal instrument of ratification according to the Article 38 stipulates that the Convention shall enter into force on the thirtieth day after the date the State submits its instrument of ratification to the Secretary-General of the United Nations [14].

On the other hand, Thailand may suffer losses in a situation where Thailand is not a party to the International Convention on the Protection of All Persons from Enforced Disappearance, thus depriving Thailand of any right of enforced disappearance endorsed in the Convention. For example, in the case of Mr. X disappearing, the issue of jurisdiction outside the territory of the state according to Article 9, paragraph two, if a national person is a victim of an 
offence outside the territory of the state that would make Thailand have no legal right to make international claims. Because Cambodian authorities are ignorant and will not investigate the case, but legitimate stakeholders claim that $\mathrm{Mr}$. $\mathrm{X}$, a Thai national, has been the victim of an offence of enforced disappearance. Thus, if Thailand is a party to this Convention, Thailand will be able to cite its jurisdiction against the Cambodian authorities for trials based on direct offences under the Convention and Article 9, paragraph two, is that when not a party, what the Thai authorities can do is to proceed in accordance with the principles of general international law or rely on the principle of international goodwill to show the seriousness of the fact-finding [21]. If the Thai state does not show seriousness or give as much importance as it should, it may be accused by the people or civil society organizations of ignoring the enforced disappearance [15].

\section{3- Research Methodology}

The study method used a mixed-method approach with a combination of the quantitative and qualitative methods for exploring legal information in nature. As well as quantitative data, which has been collected from 213 respondents between July and August 2021, using a convenient sampling technique. A Focus Group Discussion (FGD) and Key informant interviews were employed for exploring and analyzing the potential impacts of qualitative information about students' and teachers' perceptions which were not covered by the structured questionnaire (Figure 2). The questionnaire included various statements and perceptions of the students were measured by the response of interviewees to the separate items at a 5-Point Likert scale analysis with typical multiple-choice options were represented from 5 pointstrongly agree, agree, no opinion, disagree, and 1-Point strongly disagree as to the Likert item with a statement. Both primary and secondary sources have been collected according to the Table 2.

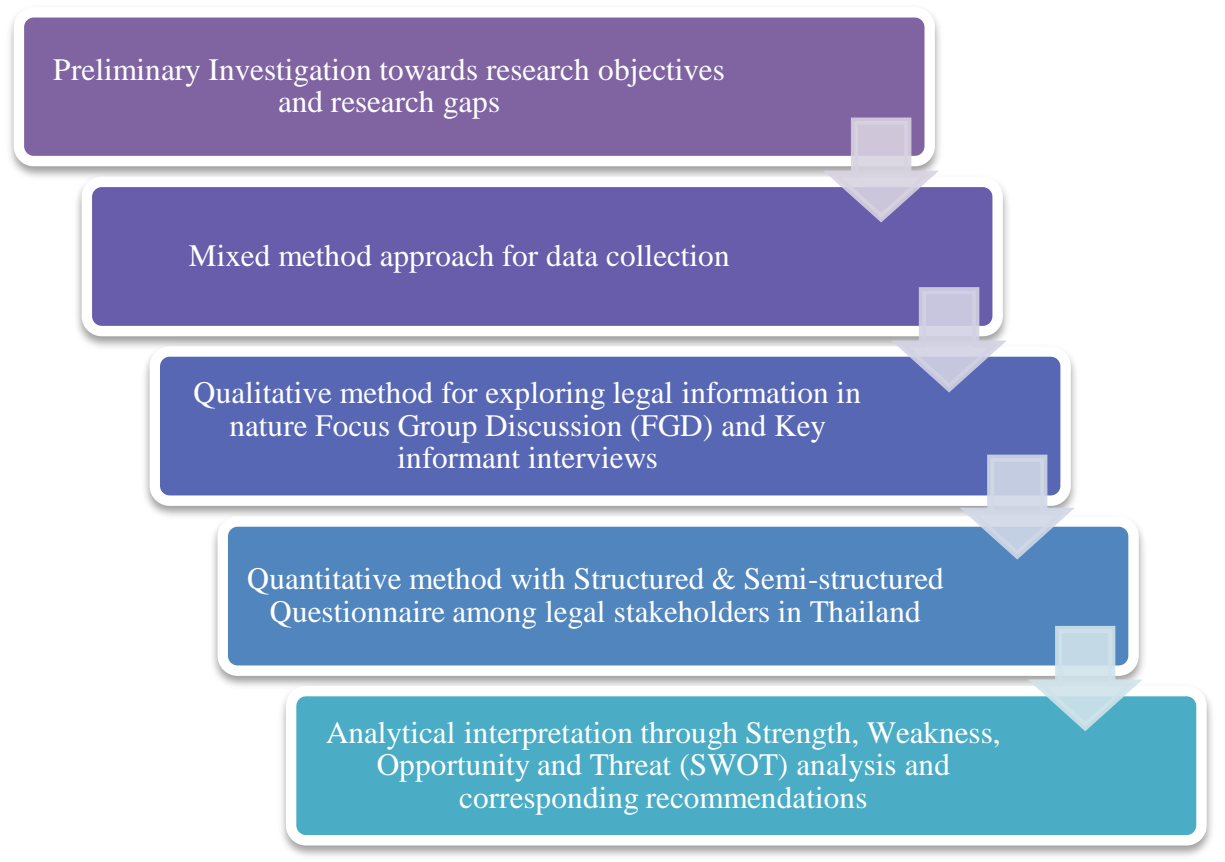

Figure 2. Conceptual framework for methodical flow of the research

Table 2. Methodological approach towards this research

\begin{tabular}{|c|c|c|c|}
\hline Research Study Questions & Method(s) & $\begin{array}{c}\text { Structured \& Semi-structured } \\
\text { Questionnaire }\end{array}$ & Sample Respondents \\
\hline $\begin{array}{l}\text { Compliance with the provisions of } \\
\text { Convention to combat enforced } \\
\text { disappearance in Thailand }\end{array}$ & Quantitative & $\begin{array}{l}\text { Structured \& Semi-structured } \\
\text { Questionnaire }\end{array}$ & $\begin{array}{l}\text { Law Students of public \& private universities } \\
\text { in Bangkok, Metropolitan Area Thailand. } \\
\text { Law Faculties of public \& private universities } \\
\text { in Bangkok, Metropolitan Area Thailand. }\end{array}$ \\
\hline $\begin{array}{l}\text { The obligations to combat enforced } \\
\text { disappearance under the national law } \\
\text { of the land. }\end{array}$ & Qualitative & $\begin{array}{l}\text { Primary sources: National } \\
\text { statutes, i.e., Constitution, Penal } \\
\text { Code / leading cases / judicial } \\
\text { opinions and so on. }\end{array}$ & $\begin{array}{l}\text { Secondary sources: Articles/ books/book- } \\
\text { chapters in the edited volume/blogs and so on. }\end{array}$ \\
\hline
\end{tabular}

Thailand's context of enforced disappearances has continued to increase cases due to the data collection of the Center of Sustainable Development Goals (SDG) and the Research and Support (SDG Move and Amnesty International Enforced Disappearances). These centres objectives are for calling human rights violations. The SDG centre was 
founded due to the number of judicial killings in the past. Especially, ensuring public access to this matter information and the protection of human freedoms by national and international law adopted by the Goal 16.10 of the United Nations. According to Goal 16.10.1, Thailand also has a group of people whose rights have been violated in the manner of expressing political opinions or deprived of academic freedom of scholars, leading to political asylum. As observations, Human Rights Watch has criticized and expressed concern about the enforced disappearances by force of the state. Although the Thai government currently does not have a specific national law on the offence of directly enforced disappearance Act. However, the study survey was conducted in Bangkok and the Metropolitan area between July and August 2021. Most backgrounds and experiences of the respondents are differed due to their occupations. To achieve the objectives of this study, the respondents were initially asked the following five general selections; strongly agree, agree, neither, disagree, strongly disagree questions. The purpose is to analyse their views on the ratification of the Convention and implementation [22].

\section{4- Results and Discussions}

- Question1: Should Thailand ratify an Enforced Disappearance Convention also specialized enact the Prevention and Suppression of Torture and Enforced Disappearance Act BE.

- Question 2: Is Thailand has enough legal instruments efficiently that could protect the victim? Is it enough?

- Question 3: Does Thailand has a general customary law or traditional obligation to comply with this Convention while holding in the process of ratification.

From Figure 3, approximately $91 \%$ of respondents have a customary obligation to comply with the Convention, and approximately $79 \%$ of respondents think Thailand should ratify and implement the provisions of the Convention. Respondents agreed that enforced disappearances would be reduced if Thailand ratified the Convention. Several respondents were of the opposite view that Thailand's ratification would reduce cases of enforced disappearances. Although Thailand has ratified but this percentage is as high as 63\%, suggesting that the ratification of the Convention has a positive correlation to reduce enforced disappearances. Hence, the following assumptions can be developed: H1: Ratification of the Convention can reduce enforced disappearance. The Conversation Group (FGD) and Key Informant Interviews (KII) argue that Thailand has ratified several international covenants and Conventions adopted by the United Nations, such as the ICC Rome Statute, the International Covenant on Civil and Political Rights. All of the above instruments expressly or implicitly recommend the fight against enforced disappearances. Therefore, it is better to sign and ratify the convention and it is accepted by the international community. The KII revealed that Thailand fails to reduce enforced disappearances. Also, the tendency of disappearance will increase due to state criticism. For this reason, international political pressure might change Thailand to ratify this Convention immediately. Therefore, the test takes into account the following factors as a fair investigation, appropriate penalties, and the fight against forced disappearance in Figure 4.

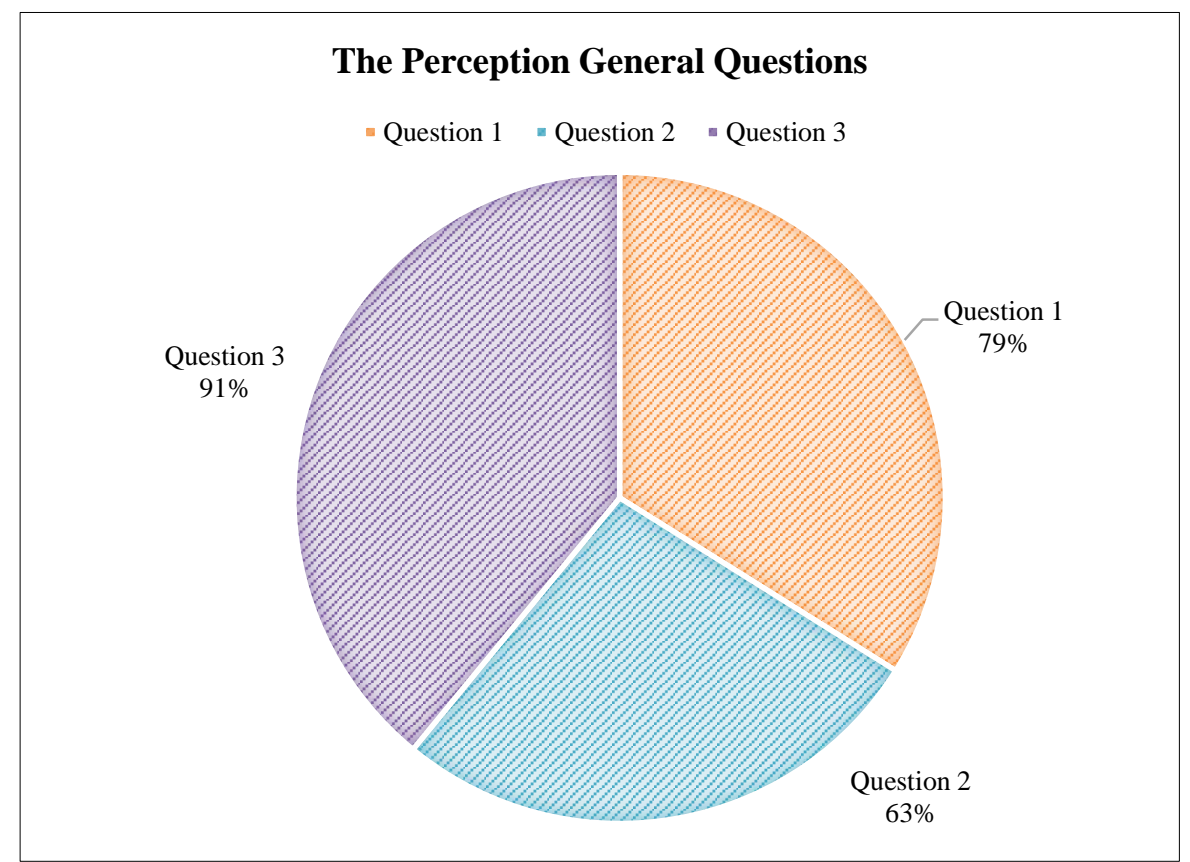

Figure 3. Thailand should ratify and comply with the Convention, ratification of the Convention will reduce on enforced disappearance, and Thailand has customary obligation to comply with the Convention 


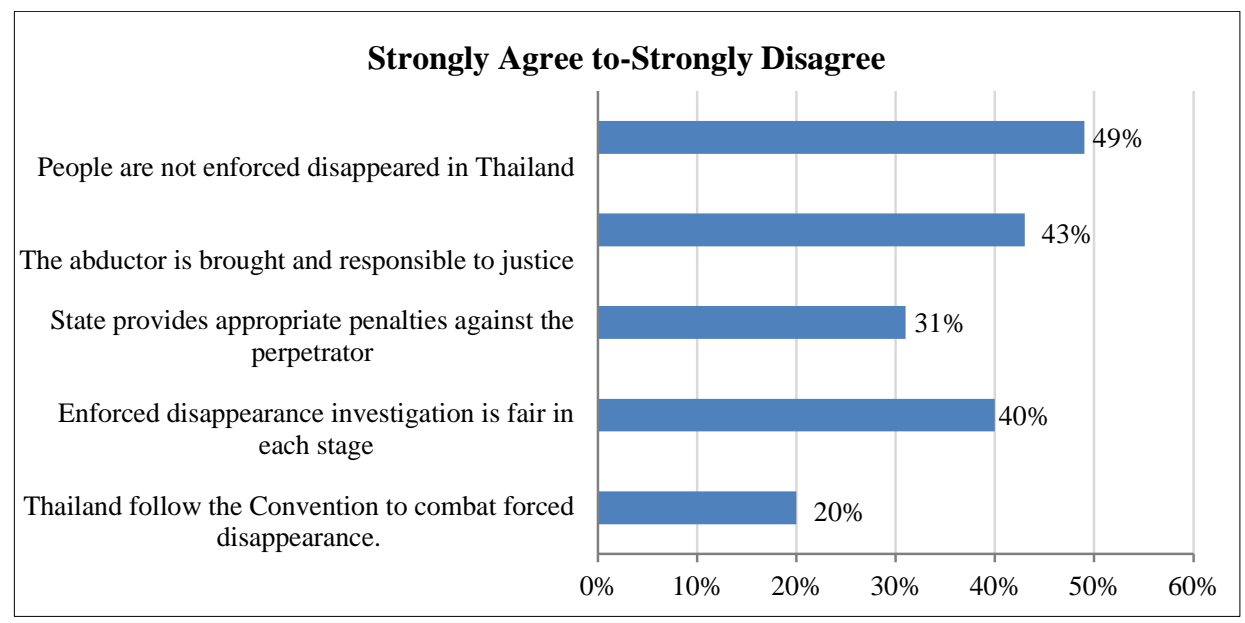

Figure 4. Limited level of compliance with the provisions of a fair investigation, penalty, and abductor brought to justice, and to combat enforced disappearance

Article 1 of this Convention, a person would be protected from enforced disappearance in situations such as internal political instability, a public emergency and war. However, from Figure 4, only $49 \%$ of respondents agreed that there is no enforced disappearance in Thailand, and only $20 \%$ of respondents believed that Thailand complies with the provisions of the Convention to Combat Enforced Disappearance. Article 3 of the Convention states that States Parties shall be responsible for prosecuting offenders. In addition, Article 4 of the Convention states that Parties might be punished for enforced disappearances under the Thai Criminal Law Code of Thailand. However, Figure 4 showed that $43 \%$ of respondents believed that the offender has been taken to court, and only $31 \%$ of the respondents believed that the offender receives an appropriate punishment under the Criminal Law Code of Thailand. The Thai has a strict responsibility to punish perpetrators regarded to provisions of Article 7. In addition, Article 12 of the Convention states that victims have the right to report to relevant authorities, and Article 3 states that states are responsible for prompt and fair investigation of allegations. However, according to Figure 4, only $40 \%$ of respondents believed that the state complied with these law statutory provisions.

Article 24 of the Convention states that victims of enforced disappearance are entitled to fair compensation. However, Figure 5 found that $19 \%$ of respondents agreed that victims of enforced disappearances were adequately compensated. The Thai government should be responsible for registering missing persons, whether by government or private sectors. Thailand must also ensure that no person is secretly abducted or detained under Article 17 of the Convention on Enforced Disappearance, and Thailand must ensure that no one is snooping on detention under Article 17 of the Convention. Only some respondents believed that the Thai government had no secret detentions in Thailand. In addition, Thailand must provide information to relatives of victims involved in Article 18 of the Convention, and more importantly, the Thai government is obliged to report progress and all relevant investigations to relatives of victims under Article 24 of the Convention. Respondents gave the opinion that relatives of the victims had access to government information. Meanwhile, only $37 \%$ of respondents thought the relatives of enforced disappearance victims had access to investigations and other progress reports from government agencies. Therefore, to answer the research question, it is concluded that the legal provisions of Thailand have not yet been enforced by the Convention on Disappearances because the national law Act has not been ratified by the government. Although, in the future, there may be ratified on the enforced disappearance Act. However, the draft of the Prevention and Suppression of Torture Act and the Disappearance is still has a controversial to make it more suitable for the context of Thailand.

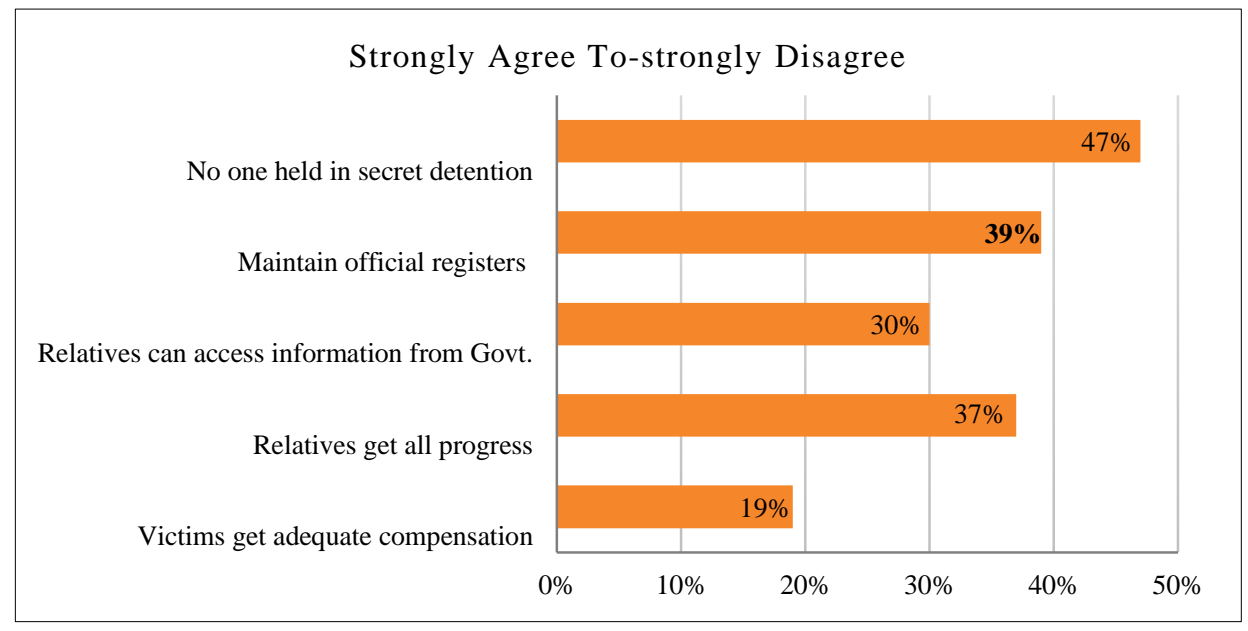

Figure 5. Illustrates a limited level of compliance with the Convention particularly on compensation, investigation and progress, accessing to information, maintaining an official registrar, and secret detention 


\section{4-1-Amendment in the Existing Act in Thailand}

Thailand has a government that functions along with the Thai constitution at the helm of its policy implementations. The hierarchy of the enactment or amendment as per Chapter I, Section 3 of the current constitution of Thailand involves the national assembly or parliament consisting of 700 representatives of the people, a council of ministers (35 ministers and 1 Prime Minister) or the cabinet of the current government and the court (Court of Justice) with essential approval exercised by the King of Thailand (Figures 6 and 7). One of the examples of such amendment is the amendment of the laws about the criminal code revision in terms of rape offence in Thailand [20]. The Criminal Code (No. 27), B.E. 2562, came into effect on 28 May 2019.

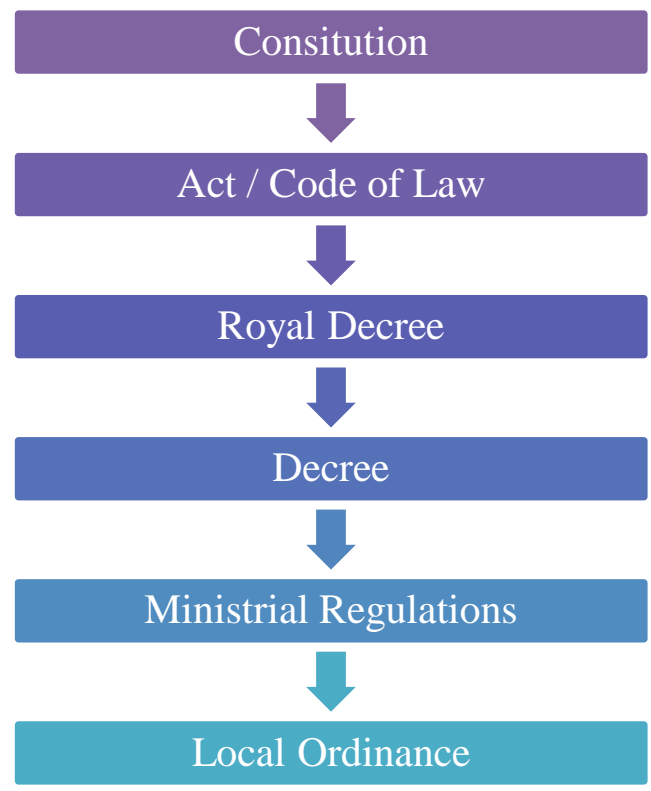

Figure 6. Hierarchy of Legal Framework in Thailand
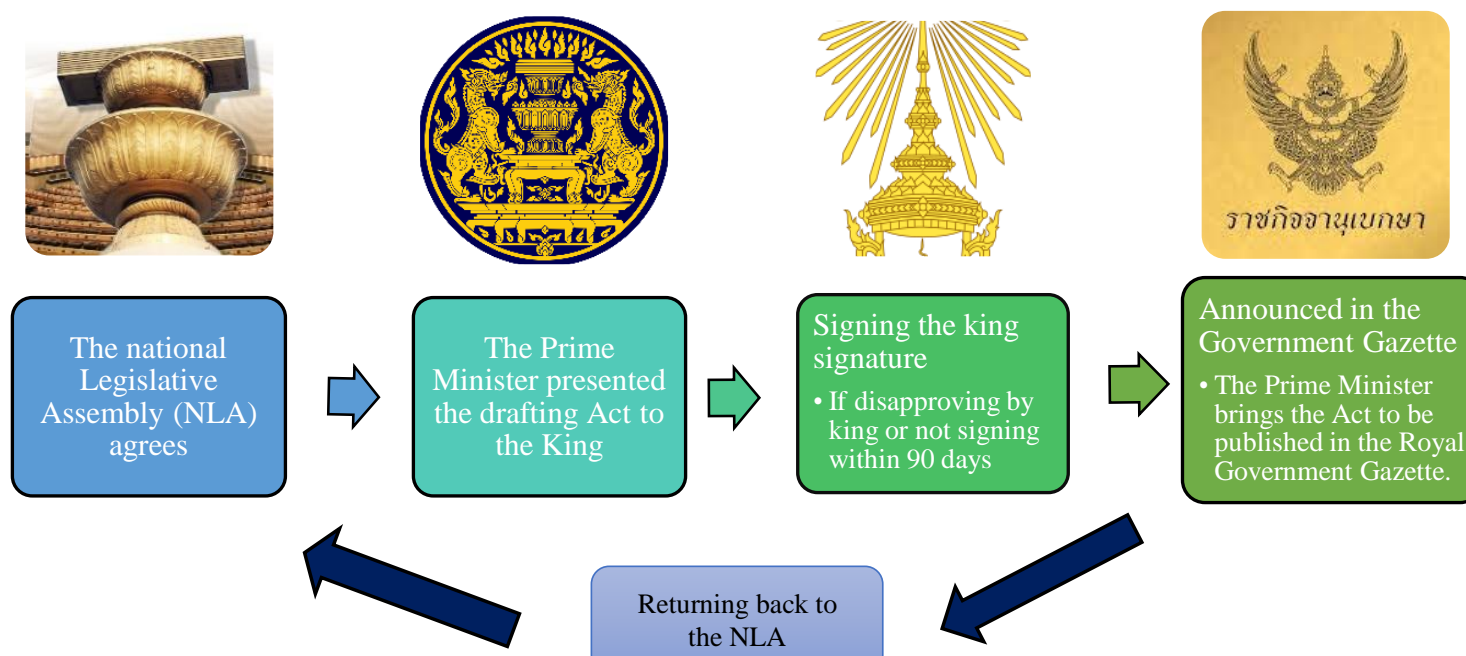

The Prime

inister presented drafting Act to the King

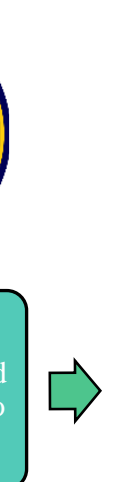

Returning back to the NLA
ราชกจจานุเนกษา

Announced in the Government Gazette

- The Prime Minister

brings the Act to be published in the Royal Government Gazette.

Figure 7. Workflow of the Royal Thai Legal Act Enactment Processes

\section{4-2-SWOT Analysis}

The Strength, Weakness, Opportunity and Threat (SWOT) analysis provided for the in-depth study of this research. The barriers and hurdles among the Thai legal system in the ratification of the CED. The following are the details of each aspect of the SWOT analysis (Figure 8): 


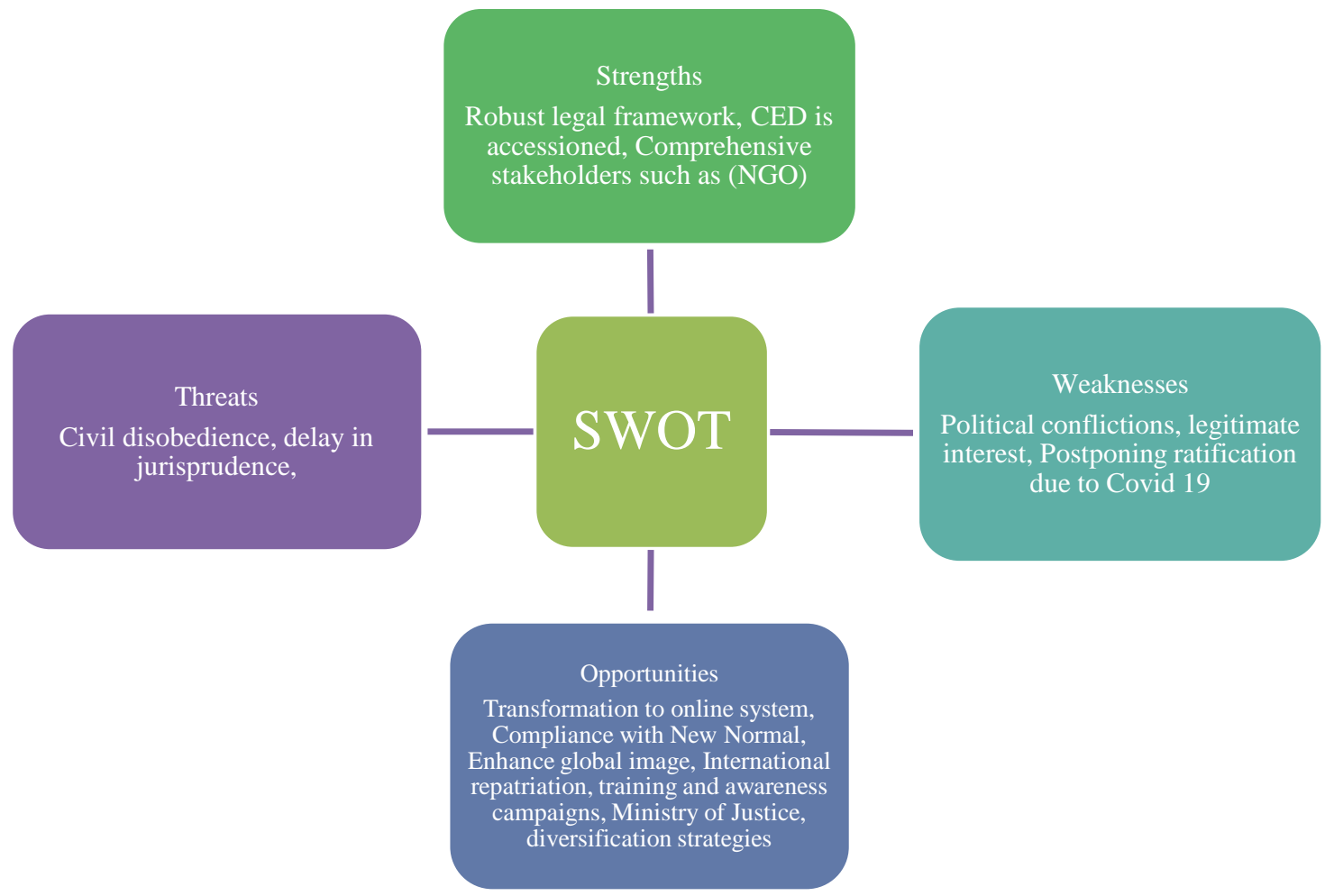

Figure 8. SWOT analysis for the study

Strengths: The strength of Thailand in terms of the legal framework is the robustness of the existing system. The well-defined ministerial regulations and responsibilities assist in the accession of the international norms. This framework and legal approach is the foundation for the adequate accession of the CED in Thailand. Another strength involves the collaboration from various stakeholders including Non-Governmental Organizations, international bodies and assistance from various development and sustainable organizations around the world. The amalgamated framework provides for the cushion to cope up with the Covid-19 pandemic. However, the implementation of the framework at the local levels are inadequate in Thailand [23].

Weaknesses: Despite the adequate legal framework in Thailand, the laws require amendments and regulatory revisions to provide sustainable growth in Thailand [24]. The weaknesses exist among the policymakers, legal machinery and departmental separation which poses a grave limitation towards implementation of the internal laws and policies. The political conflictions and recurring military regimes at the national level disable the adequacy of justice in Thailand. The legitimate interest in the development-oriented approach is found to be lacking in terms of the political mindset in Thailand. The Covid-19 pandemic has been contributing towards these weaknesses as the offices, ministries and departments were facing grave danger of inadequacies with Work from Home (WFH) or even postponing of the judiciary in several provinces in Thailand. This was found to be a root cause of the delay in terms of the adoption of adequate rules and regulations in Thailand.

Opportunities: There are several opportunities prevailing in the wake of the Covid-19 pandemic for improve and enhance the overall reach of its legal systems. One of the major lessons learnt from the Covid-19 pandemic is that it is possible to work online. Therefore, the Thai legal system needs to transform into an online system. The concept of new normal with compliance in times of the Covid-19 pandemic could be a landmark in the judiciary and legal system in Thailand. On the other hand, ratifications of international regulations and legal systems in Thailand would ensure the enhancement of the global image of Thailand. The reach of the Thai legal system beyond the international boundaries is to be strengthened with the adoption and adaptation of laws such as international repatriation laws. The department collaboration and comprehensive planning at the ministerial level would ensure the adequate implementation of the Thai laws. This could be achieved through adequate training and awareness generation among the Thai citizens. The preliminary training the workshops conducted among the public works departments such as electric, police, fire and emergency services departments would enhance the reach of the legal system in Thailand. Under one umbrella of the Thai ministries including the Ministry of Justice, diverse strategies should be adopted in order to enhance the reach of the CED goals and mission of the SDGs in Thailand [25].

Threats: Thailand is found to be lacking in a collaborative approach towards implementing fair and legal practices with few sections of the Thai population. The Civil disobedience movement throughout 2020 in the capital city of Bangkok and the inadequate dealing by the civil services and police were highly criticized in Thailand. However, human rights were found to be negligible during the face-off between the Thai population and police forces. The Covid-19 
pandemic enhanced the situation with lockdown and curfews in various parts of Thailand. The direct impact was observed in terms of the delay in jurisprudence. The courts took months to resume the court cases through the online platforms and the meeting of the representatives of the National Legislative Assembly (NLA) was postponed several times.

For decades, Thailand has been struggling with a sound political system. The barriers to ratifying the CED have been steadily increasing. Similar to other politically unstable countries such as Colombia [26], the transition to political stability witnessed the accession and ratification of international conventions curbing down the Human Right Violations (HRV).

Another country that is struggling in terms of enforced disappearances has been Bangladesh and Pakistan [27, 28]. Similar to the unstable political oppression that has been violating human rights among its citizens, the CED enhances the legal mechanisms for these countries to empower and legally bind policies to enhance the human rights of their citizens.

The intersection of both legal frameworks, sovereignty and biopolitical parameters has been working against the ratification of the CED in Thailand. The amalgamated impact of the political, governmental, human rights violations, legal limitations, and enhanced vulnerabilities from the Covid-19 pandemic is consistent with the rule of law in Thailand.

Forcible disappearance is occurring in Thailand, with several nationalities from ASEAN countries being affected in Thailand. Due to the relaxation of immigration policies as an ASEAN member country, human trafficking among the nationals of Myanmar, Vietnam, and Cambodia has increased. The obligation of Thailand to provide decent work for all laborers, as per the agreement of Thailand towards the Declaration of Fundamental Principles and Rights at Work, ILO 1988, has to be implemented through the ratification of the CED to ensure the security and human rights of the people.

\section{5- Conclusions}

Thailand should ratify the International Convention for the Protection of all Persons from Enforced Disappearance (CED) to be followed by the principles of human rights and United Nations Sustainable Development Goal 16 on the protection of freedoms. Human rights are fundamental rights in humans that include both natural and legal rights and serve as the foundation for all humankind to live together in equality and fairness. An increase in the efficiency of political mechanisms would bring human values and dignity. Ratification of CED by Thailand would not only protect the Thai population but also the neighboring countries in the ASEAN region. Free labor and immigration policies are to be revisited after ratification in terms of enforced disappearance. Human rights violations would be subject to adequate legal action after ratification. Under the ratified CED, insufficient political influence among vulnerable people will be limited.

The following are the recommendations from this research:

- Revisiting the ratification process among the governmental channels, i.e., the parliamentary procedures for the accession and ratification of international conventions.

- Adequate measures regarding reducing the impacts of the Covid-19 pandemic on the general procedures of legal implications and policy formulations.

- Appropriate measures to curtail the damage from civil disobedience and enforced disappearances in the rural and remote locations in Thailand.

- Adequate collaborative mechanisms between all stakeholders, including non-governmental organizations (NGOs) and local government bodies, are required.

- Strengthening human rights violation reduction measures through appropriate government channels.

- Generation of awareness of the general labor force through training and workshops. These might be conducted online in the wake of Covid-19 pandemic.

The next step of this research will explore the further strengthening of migrant workers' rights in Thailand. The convention on the protection of the rights of migrant workers and their families, and its accession and ratification, are due in Thailand. This enhances the vulnerabilities of the migrant workers in Thailand, especially during and after the Covid-19 pandemic.

\section{6- Declarations}

\section{6-1-Author Contributions}

S.P. and S.L. contributed to the design and implementation of the research, to the analysis of the results and to the writing of the manuscript. All authors have read and agreed to the published version of the manuscript. 


\section{6-2-Data Availability Statement}

Data sharing is not applicable to this article.

\section{6-3- Funding and Acknowledgements}

The authors would like to thank the School of Political Science and Laws, and College of Graduate Studies (CGS) at Walailak University for supporting the research. This research was financially supported by the new strategic research project (P2P) fiscal year 2022, Walailak University, Thailand.

\section{6-4- Conflicts of Interest}

The authors declare that there is no conflict of interests regarding the publication of this manuscript. In addition, the ethical issues, including plagiarism, informed consent, misconduct, data fabrication and/or falsification, double publication and/or submission, and redundancies have been completely observed by the authors.

\section{7- References}

[1] Tellez, I. L., \& Yerovi Proaño, S. (2018). The International Human Rights System and the Subject of Lawfare. Revista de La Facultad de Jurisprudencia RFJ, 34. doi:10.26807/rfj.v0i4.106.

[2] OHCHR. (Y.19). "Disappearances: Working Group on Enforced or Involuntary Disappearances". Available online: https://www.ohchr.org/en/issues/disappearances/pages/disappearancesindex.aspx (accessed on November 2020).

[3] Milić, T. (2010). International Convention for the Protection of All Persons from Enforced Disappearance. Medjunarodni problemi, 62(1), 37-64. doi:10.2298/MEDJP1001037M.

[4] Teerawattanachai. S. (2019). Measures for the Prevention and Suppression of" Enforced Disappearances. International Obligations that Thailand Must Follow. Krisdika Journal, 14(6), 16-20.

[5] Hanpichanchai, K. (2009). The International Convention for the Protection of all Persons from Enforced Disappearance: Legal Impacts on Thailand. Journal of Thai Justice System 2 no. 3 (2009): 35-45.

[6] McCrory, S. (2007). The International Convention for the Protection of all Persons from Enforced Disappearance. Human rights Law review, 7(3), 545-566. doi:10.1093/hrlr/ngm021.

[7] Office of Council of State. Constitution of the Kingdom of Thailand 2017. Available online: https://www.krisdika.go.th/law?lawId=1 (accessed on November 2021).

[8] Vicente, A., \& Nudd, E. (2021). Addressing a forgotten struggle: Victims of enforced disappearance in Africa. Torture Journal, 31(2), 68-82. doi:10.7146/torture.v31i2.125518.

[9] Citroni, G. (2016). The Specialist Chambers of Kosovo. Journal of International Criminal Justice, 14(1). doi:10.1093/jicj/mqv084.

[10] Vibhute, K. (2008). The 2007 international convention against enforced disappearance: some reflections. Mizan Law Review, 2(2), 281-310. doi:10.4314/mlr.v2i2.55627.

[11] Romashkin, S. (2020). Historical background and key elements of crime accordingly to International Convention for the Protection of all Persons from Enforced Disappearance. Revista Amazonia Investiga, 9(28), 536-544. doi:10.34069/ai/2020.28.04.58.

[12] Johansen, L. V., \& Kjær, A. L. (2021). Ambition and reality: Reforms of legal studies at the Faculty of Law at the University of Copenhagen. In Research Handbook on Modern Legal Realism (pp. 223-239). Edward Elgar Publishing. doi:10.4337/9781788117777.00027.

[13] Enforcing missing persons: international standard vs Thai standard. (2021). Available online: https://www.the101.world/enforced-disappearance (accessed on November 2021).

[14] OHCHR. Convention CED. (2021). Available online: https://www.ohchr.org/en/hrbodies/ced/pages/conventionced.aspx (accessed on November 2021).

[15] Srivuthiprapa. P. (2020). Law-more for law. Available online: https://law.mfu.ac.th/law-news/law-detail/detail/News/6856.html (accessed on November 2021).

[16] Wolffenbuttel, A. (2021). Enforced Disappearances: Applicable to Political Organizations?. Virginia Journal of International Law Online, 61(150).

[17] Pivawatthanapanich. P. (2005). Explanation of International Law. Bangkok: Thammasat University Press, Bangkok, Thailand.

[18] Pachusanond, C. M. V. (2021). Internal Processes of the Executive in Becoming a Party to and Implementing Obligations under an International Convention. Chulalongkorn Law Journal, 39(1), 1-34. 
[19] Natipawet. V. (2020). The draft prevention and suppression of torture and enforced disappearance Act B.E....: Case study on criminal liability structure of the crime of involuntary. Journal of Thaksin University Library, 9, 1-18.

[20] Yusawat, S. (2019). The Content of the 27th Revision of Criminal Code: Study on Rape. Naresuan University Law Journal, 12(2), 53-63.

[21] Sarkin, J. (2012). Why the Prohibition of Enforced Disappearance Has Attained Jus Cogens Status in International Law. Nordic Journal of International Law, 81(4), 537-584. doi:10.1163/15718107-08104006.

[22] Gatti, G., Irazuzta, I., \& Martínez, M. (2021). Inverted Exception. Ideas for Thinking about the New Disappearances through Two Case Studies. Journal of Latin American Cultural Studies, 29(4), 581-604. doi:10.1080/13569325.2020.1839869.

[23] Pathak, S., \& Ahmad, M. M. (2018). Role of government in flood disaster recovery for SMEs in Pathumthani province, Thailand. Natural Hazards, 93(2), 957-966. doi:10.1007/s11069-018-3335-7.

[24] Current International Legal Issues: Thailand. (2019). Asian Yearbook of International Law, Volume 23 (2017), 71-77. doi:10.1163/9789004415829_007.

[25] Citroni, G. (2016). The Specialist Chambers of Kosovo: The Applicable Law and the Special Challenges Related to the Crime of Enforced Disappearance. Journal of International Criminal Justice, 14(1), 123-143. doi:10.1093/jicj/mqv084.

[26] Humphrey, M. (2018). The political lives of the 'disappeared' in the transition from conflict to peace in Colombia. Politics, Religion and Ideology, 19(4), 452-470. doi:10.1080/21567689.2018.1538671.

[27] Bari, M. E. (2021). The Use of Enforced Disappearance in Bangladesh as a Tool of Political Oppression: Human Rights in Retreat. The Michigan State Journal of International Law, 29, 413.

[28] Prideaux, W. F. Ameer Yakoob Khan. (1880) Notes and Queries, Oxford Academic 6-I(25). doi: 10.1093/nq/s6-i.25.506a. 


\section{Appendix I}

The following questions ask you about Thailand's context of enforced disappearances. Tick the number that most closely indicates in your preference.

Please specify by checking the Respondent Type that most closely matches your position

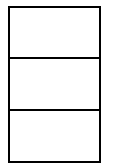

Law Student

Law Faculty

Other

Tick the correct numeric response to each question:

\begin{tabular}{rr}
\hline Question \\
\hline Part I \\
\hline
\end{tabular}

1. Thailand follows the Convention to combat forced disappearance.

(1)
Strongly
Agree

2. Thailand Enforced disappearance investigation is fair in each stage

3. Thailand provides appropriate penalties against the perpetrator

4. The abductor is brought and responsible to justice
(1)

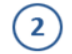

Agree

(2)

Strongly

Agree

(1)

Strongly

Agree

(1)

Strongly

Agree

(1)

Strongly

Agree
Agree

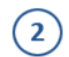

Agree

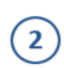

Agree

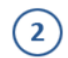

Agree
(3)

Neither

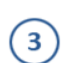

Neither

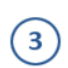

Neither

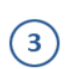

Neither

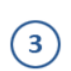

(3)

Neither
(4)

Disagree

(4)

Disagree

(4)

Disagree

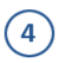

Disagree

(4)

Disagree
(5)

Strongly

Disagree

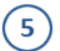

Strongly

Disagree

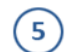

Strongly

Disagree

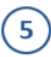

Strongly

Disagree

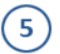

Strongly Disagree

\section{Part II}

1. The Thai government has no one held in secret detention

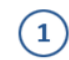

Strongly Agree

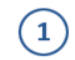

2. The Thai government maintains official registers for missing person

Strongly Agree

3. The relatives of the victims can access to government information

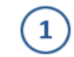

Strongly Agree

4. Relatives get all progress and all relevant investigations

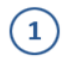

Strongly Agree

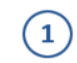

5. The victims of enforced disappearances get adequate compensation.

Strongly Agree

\section{(2)}

Agree

(2)

Agree

(2)

Agree

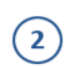

Agree

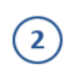

Agree
(3)

Neither

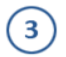

Neither

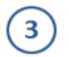

Neither

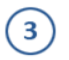

Neither

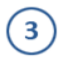

Neither
(4)

Disagree

(4) Disagree

(4) Disagree

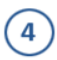
Disagree

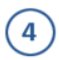
Disagree

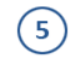

Strongly Disagree

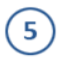

Strongly Disagree

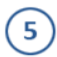

Strongly Disagree

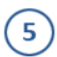

Strongly Disagree

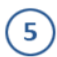

Strongly Disagree

\section{Part III}

1. Thailand should ratify an Enforced Disappearance Convention also specialized enact the Prevention and Suppression of Torture and Enforced Disappearance Act BE.

\section{(1) Strongly Agree}

2. Thailand has enough legal instruments efficiently that could protect the victim

3. Thailand has a general customary law or traditional obligation to comply with this Convention while holding in the process of ratification
(1)

Strongly Agree

(1)

Strongly Agree

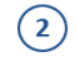

Agree

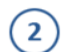

Agree

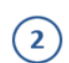

Agree

\section{(3)}

Neither

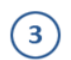

Neither

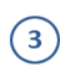

Neither
(4)

Disagree

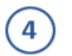

Disagree

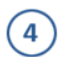

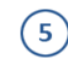

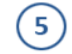

Strongly Disagree

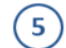

Strongly

Disagree

Strongly Disagree 